\title{
The Effect of Small Cell Size on the Sweetness of Cabbage (Brassica oleracea L.) Leaves
}

\author{
Yasutaka Kano \\ Ishikawa Prefectural University, Nonoichi, Ishikawa 921-8836, Japan
}

\begin{abstract}
Head weight of cabbage plants grown using half the nitrogen fertilizer applied to control plants (hereinafter referred to as the half-treatment group) and plants harvested on 22 November (November group) was markedly less than that obtained from control plants to which the standard amount of nitrogen fertilizer was applied and harvested on 29 July (July group). Cells from the half-treatment and the leaves from the November groups were smaller than those of the control and the July groups, respectively. Glucose and fructose content in the halftreatment and the November groups was higher than in the control and the July groups. It is therefore suggested that the higher sugar content in leaves of cabbage plants grown on media containing less nitrogen fertilizer and at low temperature occurs in response to the smaller cells in the leaves.
\end{abstract}

Key Words: Brassica oleracea L., cell size, low temperature, nitrogen fertilizer, sugar accumulation.

\section{Introduction}

Given that increasing the amount of nitrogen fertilizer is a relatively simple method for increasing the yields of leaf vegetables, growers are often inclined to apply more nitrogen fertilizer than is necessary. This increased application of nitrogen fertilizer can cause several problems in the quality of leaf vegetables. For example, oxalic acid, which promotes calculus formation, accumulates in spinach plants in response to increased nitrogen nutrients (Ota and Kagawa, 1996), and sugar content increases in numerous vegetables in response to nitrogen deficiency. In the leaves of cabbage for example, nitrogen deficiency caused an increase in free sugar content, especially that of sucrose (Hara, 1989). Conversely, the sugar content in spinach has been observed to decrease in response to increased application of nitrogen fertilizer (Takebe et al., 1995; Watanabe et al., 1988).

Furthermore, although most cabbage in Japan is cultivated outdoors using several cultivars to ensure yearround production, the nutritive value of cabbage varies at the time of shipping (Yano et al., 1981). Sugar content of cabbage has been observed to vary on an annual basis being low in summer and high during winter (Yano et al., 1981), which suggests that sugar content in cabbage is closely related to the temperature at which cabbage

Received; May 26, 2007. Accepted; October 26, 2007.

E-mail: gansho@ishikawa-pu.ac.jp. is cultivated. Cabbages with a high sugar content are of particular value for uncooked use, such as for salads.

Kano illustrated that cell size in melon fruit is closely related to sugar accumulation (Kano, 2003, 2004, 2005). Furthermore, sugar accumulation has been observed to increase markedly in fruits that developed at higher temperatures owing to an increase in the number of larger cells (Kano and Fukuoka, 2006). The size of the vacuoles in cabbage leaves decrease during periods of cold acclimation and the sugar content in the leaves increases (Suzuki et al., 1999), suggesting that the sugar content in plant organs is directly related to the size of their cells. Consequently, the manipulation of cell size in cabbage cultivation to produce sweeter cabbage has received considerable interest.

As sugar accumulation in plant organs is closely related with sugar metabolism affected by growing conditions, the effects of nitrogen fertilizer and low temperature on cell size and sugar accumulation in the leaves of cabbage were examined.

\section{Materials and Methods}

Plant materials

Experiment 1

Standard nitrogen levels (the control) employed by farmers in Ishikawa Prefecture, Japan for cabbage cultivation, and half the amount of nitrogen used for the control (half-treatment group) were used in this study. The experiments were conducted in a sandy soil field to which barnyard manure was applied at $2000 \mathrm{~kg}$ per 
$10 \mathrm{a}$ in the spring of the previous year. Two fields of $1.4 \mathrm{~m}$ wide and $30 \mathrm{~m}$ long were employed, with each field divided into two plots, the control field and the half-treatment field. In the control soil, $21 \mathrm{~g} \cdot \mathrm{m}^{-2}$ of $\mathrm{N}$, $29 \mathrm{~g} \cdot \mathrm{m}^{-2}$ of $\mathrm{P}_{2} \mathrm{O}_{5}$ and $21 \mathrm{~g} \cdot \mathrm{m}^{-2}$ of $\mathrm{K}_{2} \mathrm{O}$ were applied as basal fertilizer, and $5 \mathrm{~g} \cdot \mathrm{m}^{-2}$ of $\mathrm{N}, \mathrm{P}_{2} \mathrm{O}_{5}$ and $\mathrm{K}_{2} \mathrm{O}$ and $3 \mathrm{~g} \cdot \mathrm{m}^{-2}$ of $\mathrm{N}$ and $\mathrm{K}_{2} \mathrm{O}$ were applied as top dressing on 31 May and 16 June, respectively. In the half-treatment soil, $14 \mathrm{~g} \cdot \mathrm{m}^{-2}$ of $\mathrm{N}, 29 \mathrm{~g} \cdot \mathrm{m}^{-2}$ of $\mathrm{P}_{2} \mathrm{O}_{5}$ and $\mathrm{K}_{2} \mathrm{O}$ were applied as the basal fertilizer with no top dressing. Cabbage seeds (Brassica oleracea L. 'Wakamine', Takii Seed Co. Ltd., Kyoto, Japan) were sown and grown in paper pots $(4.7 \mathrm{~cm}$ length, $4.7 \mathrm{~cm}$ width, and $5 \mathrm{~cm}$ depth) filled with Yosaku \#1 compost (vermiculite with $500 \mathrm{mg}$ of $\mathrm{N}, 400 \mathrm{mg}$ of $\mathrm{P}$, and $400 \mathrm{mg}$ of $\mathrm{K}$ per liter of vermiculite, Chisso Asahi Fertilizer Co. Ltd., Tokyo, Japan) (50\%) and soil (50\%) in a plastic film greenhouse. Uniformly sized seedlings were planted in staggered rows on 19 May with $0.35 \mathrm{~m}$ between plants in the control and half-treatment fields. Five plants were collected from each of the respective fields 82 days after sowing (29 July) and the head weight of the plants was measured. The third, fourth and fifth leaves from the outermost head leaves were collected and weighed, and the cell number, size, and sugar content in the leaves were measured.

Experiment 2

Cabbage seeds (B. oleracea L. 'Okina', Takii Seed Co. Ltd.) were sown in paper pots on 9 May and 28 July. Uniformly sized seedlings were planted in the field on 19 May and 22 September with $0.35 \mathrm{~m}$ between plants. In the field, a basal fertilizer containing $21 \mathrm{~g} \cdot \mathrm{m}^{-2}$ of $\mathrm{N}, 29 \mathrm{~g} \cdot \mathrm{m}^{-2}$ of $\mathrm{P}_{2} \mathrm{O}_{5}$ and $21 \mathrm{~g} \cdot \mathrm{m}^{-2}$ of $\mathrm{K}_{2} \mathrm{O}$ was applied, and a top dressing containing $5 \mathrm{~g} \cdot \mathrm{m}^{-2}$ of $\mathrm{N}, \mathrm{P}_{2} \mathrm{O}_{5}$ and $\mathrm{K}_{2} \mathrm{O}$ and $3 \mathrm{~g} \cdot \mathrm{m}^{-2}$ of $\mathrm{N}$ and $\mathrm{K}_{2} \mathrm{O}$ was applied on 31 May and 16 June, respectively. Of the plants sown 9 May, five plants were collected on 29 July (July plants) and on 22 November from plants sown on 28 July (November plants), respectively. The third and fourth outermost leaves were collected from the heads of plants in both treatments for analysis of cell number, size, and sugar content.

\section{Measurements of cell number and size in the leaf}

Two quadrangular samples weighing approximately $0.3 \mathrm{~g}$ were removed using a scalpel from the central portion of the leaf between the main vein and the leaf margin to measure the cell number and size, and for sugar analysis. Each quadrangle was then immersed increasing concentrations of ethanol $(70 \%, 80 \%, 90 \%$, and $100 \%$ ), before being infiltrated with normal butanol and embedded in paraffin. Seven $10 \mu \mathrm{m}$-thick cross sections were then prepared from these paraffin blocks and the clearest section from each quadrangle for each treatment was then examined under a microscope. Cell size was measured at two locations between the veins in the cross section of one quadrangle. Cells lying on a perpendicular line to the upper leaf surface were counted and measured for their maximum diameter (Fig. 1).

\section{Sugar analysis}

Another quadrangle was homogenized in $5 \mathrm{~mL}$ of water (Polytron, PT10/35, Kinematica, Littau-luzen, Switzerland) before being centrifuged at $8000 \times \mathrm{g}$ for 15 minutes (Iwaki, CFM-100, Tokyo, Japan) and filtered through a $0.45-\mu \mathrm{m}$ PTFE hydrophilic filter (Millipore, Massachusetts, USA). Forty microliters of the filtrate was injected into an HPLC (Shimadzu Inc., LC-10ADvp, Kyoto, Japan) fitted with a refractive index detector (Shimadzu Inc., RID-10A) with a Shim-pack SCR-101C (Shimadzu Inc.) at $0.8 \mathrm{~mL} \cdot \mathrm{min}^{-1}$ at $80^{\circ} \mathrm{C}$. To determine the presence and concentrations of each sugar, 40- $\mu 1$ solutions of sucrose, glucose and fructose, each at $20 \mathrm{~g} \cdot \mathrm{L}^{-1}$ were injected into the HPLC before injection of the filtrates. In addition, sucrose, glucose and fructose content in the samples in $5 \mathrm{~mL}$ of water between boiled and not boiled was not statistically different.

\section{Results}

\section{Experiment 1}

The mean head weight obtained for the half-treatment was $2283 \mathrm{~g}$, which was $523 \mathrm{~g}$ less than that of the control (Table 1). The mean weight of leaves from the halftreatment was $45.5 \mathrm{~g}$, which was $11 \mathrm{~g}$ less than that of the control. The number of cell layers in the cross section

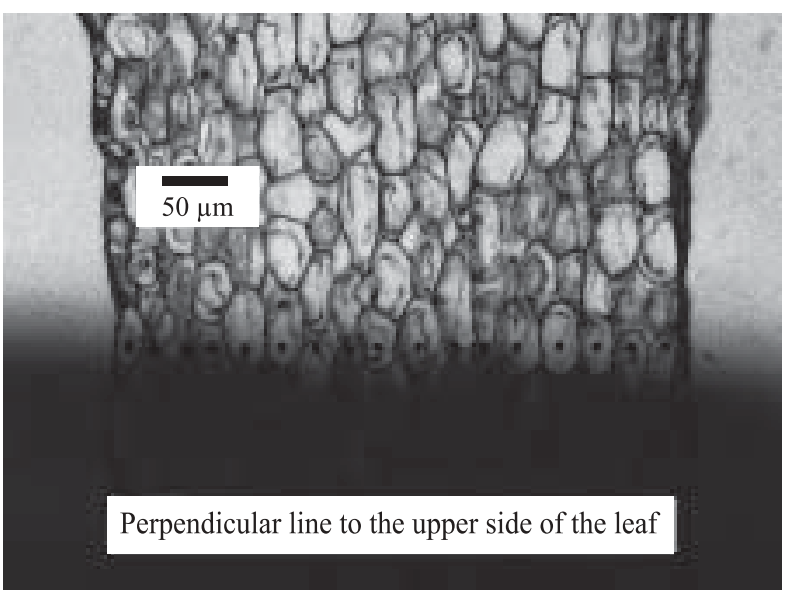

Fig. 1. Photomicrograph to show size and number of cells sampled in the leaf of the cabbage 'Wakamine'. The black dots superimposed on cells indicate the actual cells measured.

Table 1. Effects of nitrogen concentration in fertilizer on the growth of cabbage.

\begin{tabular}{lcccc}
\hline \hline \multicolumn{1}{c}{ Treatment } & Head weight $(\mathrm{g})$ & $\mathrm{n}$ & Leaf weight $(\mathrm{g})$ & $\mathrm{n}$ \\
\hline Control & $2806 \pm 292$ & 5 & $56.3 \pm 12.9$ & 15 \\
Half & $2283 \pm 400$ & 5 & $45.5 \pm 10.1$ & 15 \\
Statistical significance & $*$ & & $*$ & \\
\hline
\end{tabular}

Control: standard nitrogen level. Half: half the amount of nitrogen used for the control. Data are the means \pm SD. * Significant at $P<0.05$ by $t$-test. 

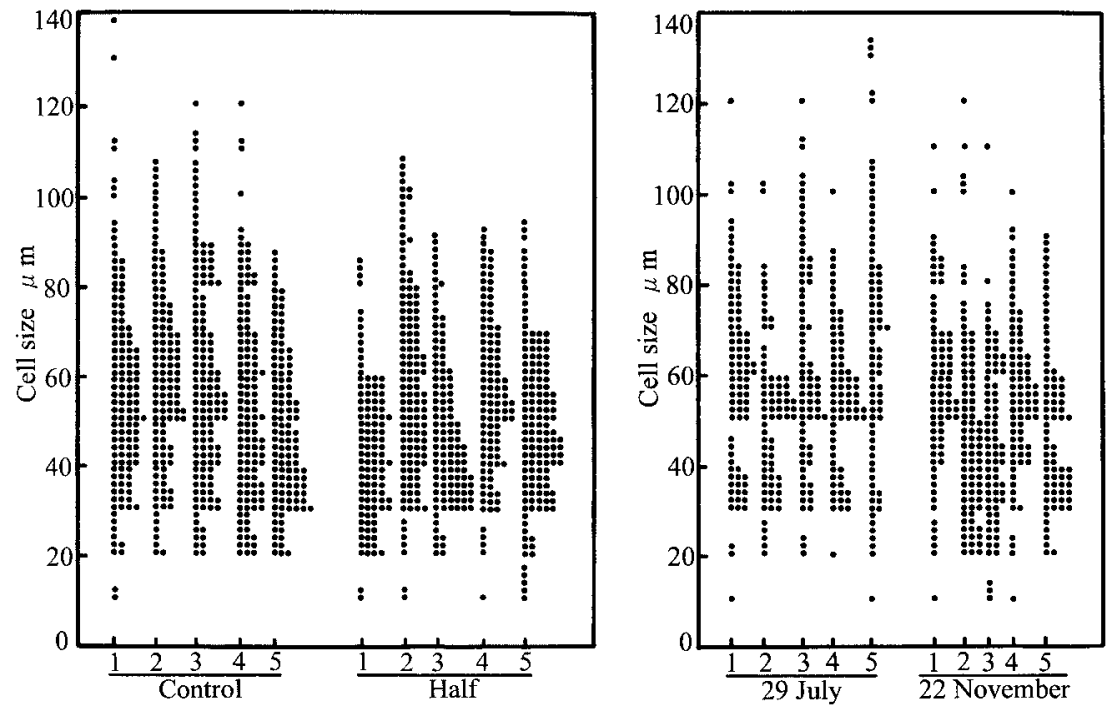

Fig. 2. Comparison of the size and the number of cells in each plant between grown at standard nitrogen levels and the half of the amount of nitrogen used for the control (left), and between collected on 29 July and 22 November (right). The numbers from 1 to 5 are the plant number used in the experiments.

Table 2. Effects of nitrogen concentration in fertilizer on cell size in leaves of cabbage.

\begin{tabular}{lcc}
\hline \multicolumn{1}{c}{ Treatment } & Cell size $(\mu \mathrm{m})$ & $\mathrm{n}$ \\
\hline Control & $55.1 \pm 21.4$ & 650 \\
Half & $51.7 \pm 19.6$ & 635 \\
Statistical significance & $* *$ & \\
\hline
\end{tabular}

Control: standard nitrogen level. Half: half the amount of nitrogen used for the control. Data are the means \pm SD. ${ }^{* *}$ Significant at $P<$ 0.01 by $t$-test.

Table 3. Effects of nitrogen concentration in fertilizer on sugar content in leaves of cabbage.

\begin{tabular}{lcccc}
\hline \hline Treatment & Sucrose & $\begin{array}{c}\text { Glucose } \\
\left(\mathrm{mg} \cdot \mathrm{g}^{-1} \mathrm{FW}\right)\end{array}$ & Fructose & $\mathrm{n}$ \\
\hline Control & 0 & $13.6 \pm 3.1$ & $7.9 \pm 1.5$ & 15 \\
Half & 0 & $16.2 \pm 2.5$ & $9.9 \pm 1.5$ & 15 \\
Statistical Significance & NS & $*$ & $* *$ & \\
\hline
\end{tabular}

Control: standard nitrogen level. Half: half the amount of nitrogen used for the control. Data are the means \pm SD. ${ }^{*},{ }^{* *}$ Significant at $P<$ 0.05 and 0.01 by $t$-test, respectively.

was approximately 20 in both treatments (data not shown). Cell diameters of the control ranged from $20 \mu \mathrm{m}$ to $100 \mu \mathrm{m}$, while the diameters of the half-treatment cabbages ranged from $20 \mu \mathrm{m}$ to $80 \mu \mathrm{m}$ (Fig. 2). The mean cell diameter of the cells from the half-treatment field was $51 \mu \mathrm{m}$, which was $4 \mu \mathrm{m}$ less than that of the control (Table 2). While sucrose was not detected, the mean glucose and fructose contents in all plants from the halftreatment field were $16.2 \mathrm{mg} \cdot \mathrm{g}^{-1} \mathrm{FW}$ and $9.9 \mathrm{mg} \cdot \mathrm{g}^{-1} \mathrm{FW}$, respectively, which was $2.6 \mathrm{mg} \cdot \mathrm{g}^{-1} \mathrm{FW}$ and $2.0 \mathrm{mg} \cdot \mathrm{g}^{-1}$ FW greater than those observed in the control plants, respectively (Table 3 ).

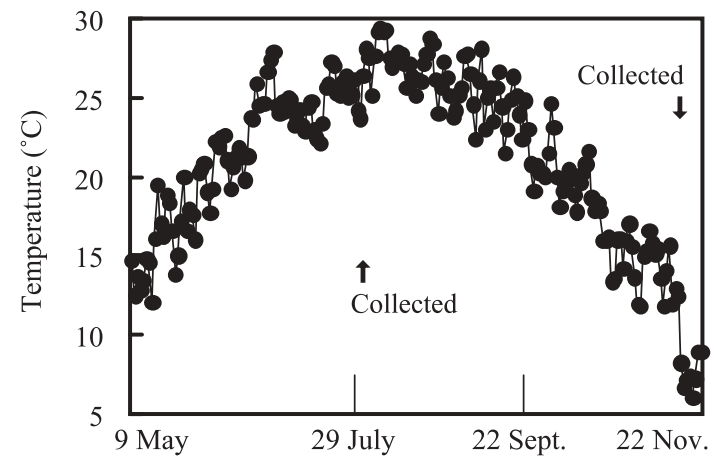

Fig. 3. Changes in daily mean temperatures during the growing period.

\section{Experiment 2}

Mean daily temperature at the time of planting on 19 May was $17.1^{\circ} \mathrm{C}$, which had increased to $28.1^{\circ} \mathrm{C}$ when the leaves were harvested on 29 July. Conversely, the temperature at the time of planting on 22 September was $24.8^{\circ} \mathrm{C}$, which had decreased to $8.9^{\circ} \mathrm{C}$ when the leaves were harvested on 22 November (Fig. 3). Monthly meteorological information for Ishikawa Prefecture revealed that daily solar radiation fluctuated markedly, but that solar radiation decreased from May to November (Fig. 4). Integrated solar radiation for the November plants from 22 September to 22 November was $565 \mathrm{MJ} \cdot \mathrm{m}^{-2}$, which was approximately half of that to which the July plants were exposed from 19 May to 29 July.

The mean head weight in November was $2100 \mathrm{~g}$, which was $700 \mathrm{~g}$ less than that in July, but the mean leaf weight in November was $65 \mathrm{~g}$, which was twice that observed in July (Table 4). The number of cell layers observed in cross section of the leaves was not significantly different between the July plants and 


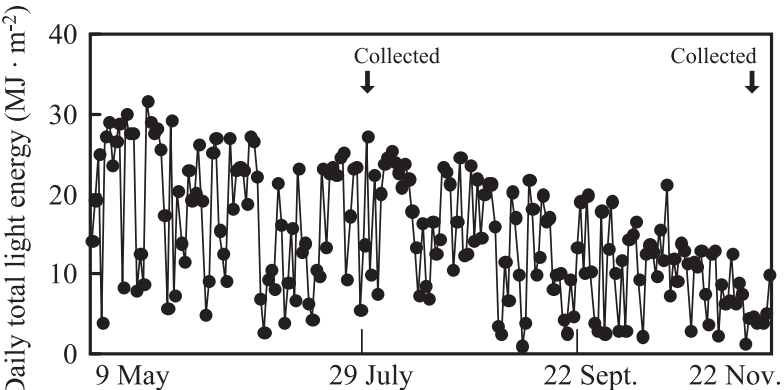

Fig. 4. Changes in daily total light energy during the growing period.

Table 4. Effects of low temperature on the growth of cabbage.

\begin{tabular}{lcccc}
\hline \hline \multicolumn{1}{c}{ Treatment } & Head weight $(\mathrm{g})$ & $\mathrm{n}$ & Leaf weight $(\mathrm{g})$ & $\mathrm{n}$ \\
\hline 29 July & $2768 \pm 274$ & 5 & $31.7 \pm 8.3$ & 15 \\
22 November & $2067 \pm 269$ & 5 & $64.9 \pm 14.1$ & 15 \\
Statistical significance & $* *$ & & $* *$ & \\
\hline
\end{tabular}

29 July: collected on 29 July. 22 November: collected on 22 November. Data are the means \pm SD. ${ }^{* *}$ Significant at $P<0.01$ by $t$-test.

Table 5. Effects of low temperature on cell size in leaves of cabbage.

\begin{tabular}{lcc}
\hline \hline \multicolumn{1}{c}{ Treatment } & Cell size $(\mu \mathrm{m})$ & $\mathrm{n}$ \\
\hline 29 July & $58.7 \pm 22.3$ & 403 \\
22 November & $51.5 \pm 19.7$ & 406 \\
Statistical significance & $* *$ & \\
\hline
\end{tabular}

29 July: collected on 29 July. 22 November: collected on 22 November. Data are the means \pm SD. ${ }^{* *}$ Significant at $P<0.01$ by $t$-test.

Table 6. Effects of low temperature on sugar content in leaves of cabbage.

\begin{tabular}{lccrc}
\hline \hline \multicolumn{1}{c}{ Treatment } & Sucrose & $\begin{array}{c}\text { Glucose } \\
\left(\mathrm{mg} \cdot \mathrm{g}^{-1} \mathrm{FW}\right)\end{array}$ & Fructose & $\mathrm{n}$ \\
\hline 29 July & $0.15 \pm 0.38$ & $11.5 \pm 4.0$ & $7.0 \pm 1.9$ & 15 \\
22 November & $0.12 \pm 0.18$ & $16.9 \pm 2.6$ & $15.3 \pm 2.4$ & 15 \\
Statistical significance & $\mathrm{ns}$ & $* *$ & $* *$ & \\
\hline
\end{tabular}

29 July: collected on 29 July. 22 November: collected on 22 November. Data are the means $\pm \mathrm{SD} .{ }^{* *}$ Significant at $P<0.01$ by $t$-test.

November plants (July; $19.1 \pm 2.5$, November; $20.5 \pm$ 3.1). While the cell diameters of the leaves harvested on 29 July ranged between $30 \mu \mathrm{m}$ and $100 \mu \mathrm{m}$, the cell diameters of leaves harvested on 22 November were generally distributed over a narrower range $(30-90 \mu \mathrm{m})$ (Fig. 2). The mean cell diameter of all the cells in November was $51.5 \mu \mathrm{m}$, which was $7.2 \mu \mathrm{m}$ less than that observed in July (Table 5). Low sucrose concentrations were observed in all of the cabbage plant leaves (Table 6). The mean glucose and fructose contents in the November plants were $16.9 \mathrm{mg} \cdot \mathrm{g}^{-1} \mathrm{FW}$ and $15.3 \mathrm{mg} \cdot \mathrm{g}^{-1}$ $\mathrm{FW}$, which were larger than the $5.4 \mathrm{mg} \cdot \mathrm{g}^{-1} \mathrm{FW}$ and $8.3 \mathrm{mg} \cdot \mathrm{g}^{-1} \mathrm{FW}$ observed in July, respectively.

\section{Discussion}

The head weight of plants grown in the half-treatment group and grown in the cold season was less than that with standard nitrogen levels and grown in the warm season, respectively. The leaf weight with half-treatment was less than that with standard treatment, but the weight in the cold season was larger than that in the warm season. Plant weight and head yield of cabbage have been demonstrated to increase with an increase in the nitrogen component of culture solutions (Hara, 1989). In addition, the growth of plug seedlings in cabbage is suppressed under low night temperatures (Kodera et al., 1992). It is suggested that the smaller head weight with the half-treatment is due to smaller leaf weight, but the smaller head weight in the cold season is due to fewer leaves owing to larger leaf weight. As the number of cells in cross section of the leaves was not different between July plants and November plants, the larger leaf weight in November plants may be caused by a greater leaf area.

The diameter of cells with the half-treatment and grown during the cold season was smaller than that observed using (control) standard nitrogen levels and grown in the warm season, respectively. While no literature has been published to date illustrating the relationship between cell size and nitrogen concentration in fertilizers, the vacuoles of cabbage leaves treated with low temperature around $1{ }^{\circ} \mathrm{C}$ have been observed to decrease (Suzuki et al., 1999). The length of parenchymatous tissue cells in leaves from Chinese cabbage grown at low temperatures is less than that obtained in plants grown at high temperatures (Ootake, 1982). Based on these findings, it is reasonable to assume that cells decrease in size in the leaves of cabbage plants grown under relatively low nitrogen fertilizer and temperature conditions.

Glucose and fructose content in the leaves of halftreated plants and those grown under low temperature was higher than that observed in plants cultivated at standard (control) nitrogen levels and high temperature. High nitrogen application to the soil has been observed to produce a decrease in glucose and fructose in cabbage leaves (Yano et al., 1981). Conversely, sucrose, glucose and fructose content in cabbage plants all increased in response to decreased nitrogen levels in culture solution (Hara, 1989), and sugar content in spinach and komatsuna leaves also increased in response to reduced nitrogen application (Takebe et al., 1995). For the effect of low temperature, elevated sugar content has been reported in cabbage harvested in late autumn to winter (Yano et al., 1981). In addition, sugar content has been reported to increase in cabbages cultivated briefly at low temperatures (Koster and Lynch, 1992; Sasaki et al., 1996, 1998; Suzuki et al., 1999). These findings show that glucose and fructose content increase in the leaves of cabbages grown using relatively less nitrogen fertilizer and low temperatures.

Most of the imported sugars then accumulate in the vacuoles of sink-tissue storage cells (Leigh et al., 1979; 
Yamaki and Ino, 1992). The numerous and relatively small vacuoles in Okubo peaches during full bloom coalesce to form one large vacuole which forces the cytoplasm to the outside of the mesocarp cell in the middle stage of fruit development (Ishida et al., 1973) and the small vacuoles of the meristematic cells increase in size and gradually coalesce as the cells enlarge and age (Esau, 1964). Eighty percent of the fresh weight of plant tissues is attributable to water, and this exists primarily in the vacuoles. Since small cells can only contain relative small vacuoles, and thus small volumes of water, the sugar content becomes larger in smaller cells if the same amount of assimilated sugars is translocated into cells. Conversely, the similarity observed in assimilated sugar concentrations in both plots of experiment 1 is thought to have been due to the equal amount of integrated solar radiation. The sugars are thus lower in the November group of experiment 2 due to the smaller amount of solar radiation (monthly weather report, Ishikawa Meteorological Agency, 2005).

By putting together these findings, the following assumptions can be made. The higher sugar content observed in the leaves of cabbage plants grown on media containing less nitrogen fertilizer and at lower temperatures can be attributed to reduced cell size in the leaves. Specifically, since cell weight is mostly attributed to vacuole weight, and since water content is low in leaves under conditions of low nitrogen and temperature owing to small cell, the sugar concentration in small cells is high. The sugar content per fresh weight of leaf material under conditions of low nitrogen and temperature is relatively higher owing to a greater number of small cells with higher sugar concentration per fresh weight.

\section{Literature Cited}

Esau, K. 1964. Vacuoles. p. 23-25. In: Plant anatomy. John Wily \& Sons, Inc., New York.

Hara, T. 1989. Effects of nitrogen, phosphorus and potassium in culture solution on the head yield and free sugar composition of cabbage. J. Japan. Soc. Hort. Sci. 58: 595-599.

Ishida, M., A. Inaba and Y. Sobajima. 1973. Physiological studies on the growth and development of peach fruits. I. Anatomical changes during the development of peach fruits. Sci. Rep. Kyoto Pref. Univ. Agr. No. 25: 1-8.

Kano, Y. 2003. Effect of GA and CPPU treatments on cell size and type of sugars accumulated in Japanese pear fruit. J. Hort. Sci. Biotech. 78: 331-334.

Kano, Y. 2004. Effect of mechanical restriction of fruit enlargement on cell size and sucrose accumulation in melon fruits (Cucumis melo L.). Acta Hort. 662: 369-372.

Kano, Y. 2005. Comparison of the effects of 4-CPA and CPPU treatment on melon cell size and sugar accumulation. Environ. Cont. Biol. 43: 147-154.

Kano, Y. and N. Fukuoka. 2006. Comparison of cell size and sugar accumulation in melon fruit (Cucumis melo L.) between early and late sowing in summer. Environ. Cont. Biol. 44: 93-102.

Kodera, K., F. Kaiho and E. Kosuga. 1992. Effect of temperature on the growth of plug seedlings in cabbage and chingen-tsai. J. Japan. Soc. Hort. Sci. 61 (Suppl. 2): 392-393 (In Japanese).

Koster, K. L. and D. V. Lynch. 1992. Solute accumulation and compartmentation during the cold acclimation of puma rye. Plant Physiol. 98: 108-113.

Leigh, R. A., T. Apree, W. A. Fuler and J. Bonfield. 1979. The location of acid invertase and sucrose in vacuoles isolated from storage roots of red beet (Beta vulgaris L.). Biochem. J. 178: 53-57.

Ootake, Y. 1982. Effect of temperature on the internal morphology and development of leaves in Chinese cabbage (Brassica campestris L.). J. Japan. Soc. Hort. Sci. 51: 329-337.

Ota, K. and A. Kagawa. 1996. Effect of nitrogen nutrients on the oxalate content in spinach plants. J. Japan. Soc. Hort. Sci. 65: $327-332$.

Sasaki, H., K. Ichimura and M. Oda. 1996. Changes in sugar content during cold acclimation and deacclimation of cabbage seedlings. Ann. Bot. 78: 365-369.

Sasaki, H., K. Ichimura, K. Okada and M. Oda. 1998. Freezing tolerance and soluble sugar contents affected by water stress during cold acclimation and deacclimation in cabbage seedlings. Sci. Hort. 76: 161-169.

Suzuki, S., Y. Takahashi, K. Masuda and T. Harada. 1999. Changes in freezing resistance, sugar constituent and cell organelle of cabbage plants during cold acclimation. J. Japan. Soc. Hort. Sci. 68 (Suppl. 1): 261 (In Japanese).

Takebe, M., T. Ishihara, K. Matsuno, J. Fujimoto and T. Yoneyama. 1995. Effect of nitrogen application on the contents of sugars, ascorbic acid, nitrate and oxalic acid in spinach (Spinacia oleracea L.) and komatsuna (Brassica campestris L.). Japan. J. Soil Sci. Plant Nutr. 66: 238-246.

Watanabe, Y., S. Shiwa and N. Shimada. 1988. Effects of intermittent solution supply on contents of ascorbic acid, sugars, nitrate and soluble oxalate of spinach plants. Japan. J. Soil Sci. Plant Nutr. 59: 563-567.

Yamaki, S. and M. Ino. 1992. Alteration of cellular compartmentation and membrane permeability to sugars in immature and mature apple fruit. J. Amer. Soc. Hort. Sci. 117: 951-954.

Yano, M., H. Ito, A. Hayami and S. Obama. 1981. Effect of cultural practices on the quality of vegetables. I. Sugar contents of cabbage and carrot. Bull. Natl. Inst. Veg. Tea Sci. A. 8: 53-67. 